SOSIOLIUM

\title{
EFEKTIVITAS PEMANFAATAN POSTER CANDI NGEMPON SEBAGAI SUMBER BELAJAR IPS DI SMP NEGERI 1 BERGAS
}

\author{
Safitri, Rudi Salam ${ }^{\bowtie}$ \\ Social Science Education Department, Faculty of Social Science, Universitas Negeri Semarang, \\ Indonesia
}

\begin{abstract}
Info Artikel
Abstrak

Sejarah Artikel:

Disubmit: Mei 2020

Direvisi: Juni 2020

Diterima: Juli 2020

Keywords:

Ngempon Temple Site,

Social Studies Learning

Sources, Effectiveness.

Penelitian ini merupakan penelitian yang bertujuan untuk mengetahui tingkat keefektifan pemanfaatan poster Candi Ngempon sebagai sumber belajar IPS di SMP Negeri 1 Bergas. Metode dalam penelitian ini yakni kuantitatif. Hasil dari penelitian ini yaitu pemanfaatan poster Candi Ngempon sebagai sumber belajar IPS efektif diterapkan, dengan hasil aktivitas belajar peserta didik yaitu sebanyak 9,67 \% termasuk dalam kriteria cukup, 61,29\% termasuk dalam kriteria tinggi, dan 29,03\% dalam kategori sangat tinggi. Hasil belajar kognitif peserta didik tinggi setelah diberikan treatment, yakni 15 peserta didik mampu mencapai nilai Kriteria Ketuntasan Minimal (KKM). Serta respon peserta didik yang tergolong tinggi,yaitu dengan hasil analisis respon peserta didik sebanyak $16,12 \%$ sangat baik, $74,19 \%$ baik dan hanya $9,67 \%$ yang termasuk dalam kriteria cukup.
\end{abstract}

Kata Kunci: Situs Candi Ngempon, Sumber Belajar IPS, Efektivitas.

\section{Abstract}

This research is a research that aims to determine the level of effectiveness of the use of Ngempon Temple posters as a learning source of social science studies in SMP Negeri 1 Bergas. The method in this study is quantitative. The results of this study is that using Ngempon Temple posters as a learning sources of social science studies can be implemented effectively, by the results of students learning activities are about $9.67 \%$ are included in the sufficient criteria, $61.29 \%$ are included in the high criteria, and $29.03 \%$ are included in the very high category. The outcomes of students' cognitive learning are high after the researcher gives a treatment, which is there are 15 students who can obtain the score of Minimum completeness criteria (KKM). The analysis of the students responses also classified in high criteria, namely $16.12 \%$ are very good, $74.19 \%$ are good, and only $9.67 \%$ are included in the sufficient criteria.

Keywords: Ngempon Temple Site, Social Studies Learning Sources, Effectiveness.

(C) 2020 Universitas Negeri Semarang

\footnotetext{
Alamat korespondensi:

Gedung C1 Lantai 1 FIS Unnes

Kampus Sekaran, Gunungpati, Semarang, 50229

E-mail: rudisalam@mail.unnes.ac.id
} E-ISSN 2685-4929 


\section{PENDAHULUAN}

Belajar merupakan proses mencari pengalaman yang kompleks, belajar sendiri terjadi pada setiap individu sepanjang hdupnya. (Santrianawati, 2018). Skinner dalam Dimyati dan Mudjiono (2009) berpandangan bahwa belajar adalah suatu perilaku, dimana pada saat seseorang belajar maka responya menjadi lebih baik, dan sebaliknya jika seseorang tidak belajar maka responnya menurun. Proses belajar terjadi karena adanya interaksi antara seseorang dengan lingkungannya (Arsyad, 2013). Melalui belajar maka dalam kehdupan manusia timbulah suatu kegiatan yang diistilahkan dengan pembelajaran.

Pembelajaran berdasarkan UndangUndang No 20 tahun 2003 merupakan suatu proses interaksi peserta didik dengan pendidik dan sumber belajar pada suatu lingkungan besar. Menurut Umar Hamaik (2007) bahwasanya pembelajaran sebagai suatu sistem, artinya pembelajaran merupakan suatu komponenkomponen yang saling berinterelasi antara satu sama lain. Komponen-komponen pembelajaran tersebut yaitu terdiri dari siswa, guru, tujuan, materi, metode, sarana/ alat, evaluasi, dan lingkungan/ konteks. Keberhasilan pembelajaran dalam arti tercapainya standar kompetensi, sangat tergantung pada kemampuan guru mengolah pembelajaran yang dapat menciptakan situasi yang memungkinkan siswa belajara sehingga merupakan titik awal berhasilnya pembelajaran (Tirto dalam Rudi Salam, 2017).

Pembelajaran adalah suatu usaha pendidik yang ditujukan kepada peserta didik agar terjadinya suatu proses perolehan ilmu dan pengetahuan, penguasaan kemahiran serta tabiat, dan pembentukan sikap dai kepercayaan pada didik, dengan kata lain pembelajaran yakni usaha untuk membantu peserta didik agar dapat belajar dengan baik, salah satu bentuk usaha pendidik dalam proses pembelajaran yaitu memanfaatkan segala sesuatu yang terdapat di lingkungan sekitar untuk dijadikan sebuah sumber belajar sebagai upaya mewujudkan tujuan secara maksimal. Sumber belajar pada dasarnya yakni segala sesuatu di luar peserta didik yang dapat dimanfaatkan dalam proses pembelajaran yang dapat memperkaya pengalaman belajar peserta didik. Sumber belajar merupakan suatu komponen penting dalam proses pembelajaran, hal ini karena sumber belajar dapat memudahkan peserta didik untuk memahami materi yang disampaikan oleh guru, dalam proses penyampaian sumber belajar kepada peserta didik akan melalui suatu media yaitu media belajar, dengan media belajar ini makna dari suatu sumber belajar akan mampu diterima serta dipahami oleh siswa (Widiastuti, 2017). Sumber belajar juga dapat diartikan sebagai segala sesuatu yang bisa digunakan sebagai tempat bahan pengajaran yang digunakan untuk belajar seseorang, dengan demikian sumber belajar dapat dikatakan sebagai segala sesuatu yang dapat dijadikan sebagai bahan atau materi untuk menambah ilmu pengetahuan dengan hal-hal baru bagi peserta didik.

Secara garis besar sumber belajar menurut Rohani (dalam Azmi, 2014) memiliki ciri-ciri sebagai berikut:

1) Sumber belajar mampu memberikan kekuatan dalam proses belajar mengajar, sehingga tujuan instruksional dapat dicapai dengan baik

2) Sumber belajar mempunyai nilai-nilai instruksional edukatif, yakni dapat merubah tingkah laku sesuai tujuan yang telah dirancang dan membawa perubahan yang sempurna.

Pengertian sumber belajar sangat luas. Namun secara umum ada beberapa klasifikasi sumber belajar. Klasifikasi sumber belajar dalam proses pembelajaran menurut buku Instructional Technoogies: The Definition and Domains of the Field dalam Rayandra Asyar (2012) menyatakan bahwa terdapat enam jenis sumber belajar yang dapat digunakan dalam proses pembelajaran yakni:

a. Pesan (Message), sebuah pesan atau materi yang bersifat formal maupun informal dapat dimanfaatkan sebagai bahan atau sumber belajar. Pesan formal itu sendiri merupakan pesan yang informasi yang dikeluarkan oleh lembaga resmi, seperti pemerintah dan non pemerintah yang diberikan oleh guru dalam situasi pembelajaran, dalam penyampaiannya bisa dalam bentuk verbal maupun dokumen. Sedangkan pesan nonformal itu sendiri merupakan pesan yang berada di sekitar tempat tinggal atau lingkungan sekitar kita.

b. Orang (people), setiap orang pada dasarnya dapat dijadikan sebagai sumber belajar namun yang membedakan adalah tingkat pengetahuan yang dimiliki oleh setiap orang. Secara umum orang dijadikan sebagai sumber belajar dapat dikelompokkan menjadi dua yakni:

1) kelompok orang yang didesain khusus sebagai sumber belajar utama yang dididik secara profesional untuk menjadi 
pengajar dan kelompok orang yang memiliki profesi lain selain tenaga pengajar

2) profesinya tidak terbatas misalnya pedagang, politisi, psikolog bahkan dokter.

c. Bahan dan program, bahan dan program merupakan sebuah format yang biasanya digunakan sebagai program pendukung dari penyimpanan sebuah media pembelajaran seperti buku, handbook, model.

d. Alat (device), alat disini merupakan benda yang berbentuk fisik atau sering disebut dengan perangkat keras atau hardware yang berfungsi sebagai sarana atau alat bantu untuk menyajikan bahan dan materi pembelajaran. Contoh alat yaitu media multimedia, Over Head Projector (OHP), media cetak(foto, koran,poster) hingga video.

e. Metode (Method), merupakan cara yang digunakan oleh guru dalam menampaikan materi pembelajaran kepada siswa untuk mencapai tujuan pembelajaran yang diharapkan

f. Latar (setting), situasi dan kondisi lingkungan belajar dimana baik yang berada di dalam sekolah maupun lingkungan yang berada diluar sekolah, dan baik yang telah dirancang khsusu atau tidak untuk kegiatan pembelajaran.

Teori lain mengklasifikasikan sumber belajar menjadi lima hal yaitu tempat, benda, orang, buku, dan peristiwa. Hal tersebut diungkapkan oleh Abdul Majid (2008). Klasifikasi tersebut secara ringkas dapat dijelaskan sebagai berikut:

a. Tempat atau lingkungan sekitar dimana seseorang dapat belajar dan melakukan perubahan tingkah laku, seperti sungai, pasar, gunung, museum.

b. Segala benda yang memungkinkan terjadinya perubahan tingkah laku peserta didik, misalnya situs sejarah.

c. Orang yang memiliki keahlian tertentu sehingga siswa dapat belajar sesuatu kepada orang tersebut.

d. Segala macam buku yang dapat dibaca secara mandiri oleh siswa.

e. Peristiwa dan fakta yang sedang terjadi.

Berdasarkan klasifikasi di atas, sumber belajar dapat digolongkan menjadi: pesan, orang, alat, bahan, teknik, dan lingkungan. Sumber belajar jika dilihat dari perancangannya secara garis besar dapat dibedakan kedalam dua macam, yaitu:

a. Sumber belajar yang dirancang (learning resources by design) yakni sumber-sumber yang secara khusus dirancang atau dikembangkan sebagai komponen sistem instruksional untuk memberikan fasilitas belajar yang terarah dan bersifat formal.

b. Sumber belajar yang dimanfaatkan (learning resources by utililization) yakni sumber belajar yang tidak didesain khusus untuk keperluan pembelajaran dan keberadaannya dapat ditemukan, diterapkan dan dimanfaatkan untuk keperluan pembelajaran (Jailani, 2016)

Sumber belajar memiliki berbagai manfaat penting dalam kegiatan pembelajaran. Sumber belajar tidak hanya bermanfaat untuk menyalurkan pesan, tetapi juga strategi, metode, dan tekniknya. Tim Pengembang Ilmu Pendidikan dari FIP UPI (dalam Wijianigsih, 2019) mengungkapkan manfaat sumber belajar adalah: Meningkatkan produktifitas pembelajaran. Memberikan kemungkinan pembelajaran yang sifatnya lebih individual. Memberikan dasar yang lebih ilmiah terhadap pembelajaran. Lebih memantapkan pembelajaran. Memungkinkan belajar secara seketika; dan Memungkinkan pembelajaran yang lebih luas. Sumber belajar bermanfaat untuk memfasilitasi kegiatan belajar agar menjadi lebih efektif dan efisien.

Sumber belajar Ilmu Pengetahuan Sosial (IPS) adalah segala sesuatu yang dapat dijadikan sebagai bahan dalam proses pembelajaran Ilmu Pengetahuan Sosial (IPS), terdapat banyak sumber belajar yang dapat dimanfaatkan dalam pembelajaran Ilmu Pengetahuan Sosial (IPS), diantaranya yaitu lingkungan sekitar.

Ilmu Pengetahuan Sosial (IPS) merupakan salah satu mata pelajaran yang diberikan mulai pada saat di tingkat pendidikan dasar yang meliputi Sekolah Dasar (SD), Madrasah Ibtidaiah (MI), dan Sekolah Dasar Luar Biasa (SDLB) sampai pada tingkat pendidikan menengah yang meliputi Sekolah Menengah Pertama (SMP), Madrasah Tsanawiah (MTs) dan Sekolah Menengah Pertama Luar Biasa (SMPLB). Ilmu Pengetahuan Sosial (IPS) sendiri mengkaji berbagai peristiwa, fakta, konsep dan generalisasi yang berkaitan dengan isu sosial. Melalui mata pelajaran IPS, peserta didik diarahkan untuk dapat menjadi warga negara Indonesia yang demokratis, dan bertanggungjawab serta warga dunia yang cinta damai (Permendiknas No 22 tahun 2006). Ilmu Pengetahuan Sosial (IPS) merupakan disiplin ilmu yang berbeda dengan disiplin ilmu yang monodisiplin, dimana disiplin ilmu ini memiliki keterpaduan antar disiplin ilmu sosial. Geografi 
memberikan wawasan yang berkenaan dengan wilayah-wilayah, sejarah memberikan wawasan tentang peristiwa-peristiwa yang terjadi pada masa lampau, ekonomi memberikan wawasan tentang berbagai macam kebutuhan manusia dan sosiologi atau antropologi memberikan wawasan yang berkenaan dengan nilai-nilai, kepercayaan, struktur sosial, lalu ilmu politik lebih kepada mengkaji hubungan antara warga dengan warga negaranya, serta negara dengan negaranya, dan psikologi membahas mengenai kondisi kejiwaan seseorang atau manusia. Sosiologi dan psikologi sosial merupakan ilmuilmu tentang perilaku seperti konsep peran, kelompok, institusi, proses interaksi dan kontrol sosial (Arif Purnomo, 2016).

Pesatnya perkembangan ilmu pengetahuan dan teknologi menuntut guru untuk bisa lebih kreatif dalam pemilihan materi, metode dan sumber belajar. Penggunaan sumber belajar yang tepat dapat meningkatkan pengetahuan peserta didik, sehingga mereka mampu bersaing dalam menghadapi perkembangan yang ada. Salah satu strategi yang dilakukan oleh guru dalam upaya meningkatkan pengetahuan peserta didik serta mencapai tujuan pembelajaran IPS di sekolah yakni dengan cara memanfaatkan sumber belajar dengan baik. Mukminan (dalam Desi Rahmawati Duhri. 2014) menegaskan salah satu ciri utama suatu pembelajaran yang berkembang adalah pembelajaran yang menggunakan sumber belajar seluas mungkin. Alat-alat yang dapat dimanfaatkan sebagai sumber belajar yang berkaitan dengan sejarah adalah situs. Menurut William Haviland (dalam Farhatin. 2016) mengatakan situs adalah tempat-tempat dimana ditemukan peninggalan-peninggalan arkeologi di kediaman manusia pada zaman dahulu. Situs sejarah setempat, seperti situs candi yang terdapat di lingkungan sekolah dapat dimanfaatkan menjadi salah satu sumber belajar IPS. Penggunaan sumber belajar tersebut selain dapat menjadi daya tarik dalam proses pembelajaran juga dapat membantu peserta didik lebih mudah memahami materi, karena dari sumber belajar tersebut peserta didik dapat melihat contoh secara langsung dan contoh tersebut sangat dekat dengan peserta didik karena terdapat di lingkungannya.

Pendidikan di era kemajuan teknologi seperti sekarang kemudahan dalam mengakses materi pembelajaran sangatlah mudah bagi peserta didik. Termasuk dalam mengakses materi pembelajaran IPS, namun seperti yang kita ketahui seiring adanya kemudahan tersebut masih kita temukan minat baca peserta didik yang masih kurang, hal ini sesuai dengan hasil observasi awal penulis, dimana salah satu guru IPS di SMP Negeri 1 Bergas yakni Bapak Sukirman. Padahal dalam proses belajar, membaca merupakan salah satu komponen penting, apalagi dalam pembelajran IPS dimana peserta didik perlu membaca secara berulang untuk dapat belajar dan memahami materi pembelajaran IPS terutama yang berkaitan dengan sejarah. Seperti yang tercantum dalam Kompetensi Dasar 4.4 siswa diharapkan mampu menguraikan kronologi perubahan, dan kesinambungan dalam kehidupan Banga Indonesia pada aspek politik, sosial, budaya, geografis, dan pendidikan sejak masa praaksara samapai masa Hindu-Buddha dan Islam. Pencapaian Kompetensi Dasar tersebut dan keberhasilan pembelajaran dengan melihat kondisi minat baca peserta didik yang masih kurang, maka perlu adanya pendukung yang lain untuk meng-cover hal tersebut, salah satunya yakni dengan memanfaatkan situs sejarah yang ada di lingkungan sekitar yakni Situs Candi Ngempon sebagai sumber belajar dalam pembelajaran IPS. Permasalahan yang terjadi terkait tantangan di era Revolusi Industri 4.0, saat ini terdapat kecenderungan bahwa mata pelajaran IPS kurang diminati peserta didik. Hal ini disebabkan karena guru dalam pembelajaran IPS masih terfokus pada model pembelajaran konvensional, kurang ditunjang dengan penggunaan model dan media pembelajaran yang inovatif, proses pembelajaran IPS kurang menyentuh aspek nilai sosial dan keterampilan sosial, serta selama ini pembelajaran IPS cenderung lebih banyak mengembangkan kemampuan menghafal materi pelajaran. (Ferani Mulianingsih, 2019). Permasalahan tersebut pula yang ditemukan dalam pembelajaran IPS di SMP Negeri 1 Bergas, dimana peserta didik merasa bosan dengan pembelajaran IPS yang telah ada. Berdasarkan hal tersebut maka diperlukannya pendukung lain dalam proses pembelajaran yang dapat memberikan daya tarik lebih bagi peserta didik, salah satunya yakni dengan memanftaakan Situs Candi Ngempon dalam pembelajaran, yang mana Situs Candi Ngempon merupakan situs sejarah yang terdapat di lingkungan SMP Negeri 1 Bergas, salah satu situs sejarah yang memiliki berbgai macam pelengkap daya dukung lain dalam keterpaduan pembelajaran IPS, diantara adanya sumber air panas serta bebatuan besar dilingkungan Candi.

Kecamatan Bergas adalah salah satu kecamatan yang terdapat di Kabupaten Semarang, dimana wilayah kecamatan ini 
memiliki situs peninggalan sejarah yang mampu dimanfaatkan dalam proses pembelajaran sebagai sumber belajar IPS, situs sejarah tersebut adalah Situs Candi Ngempon. Situs Candi Ngempon adalah situs sejarah yang ditemukan di Kelurahan Ngempon, Kecamatan Bergas, Kabupaten Semarang. Candi Ngempon merupakan salah satu situs candi peninggalan masa Hindu yang pada awal ditemukan oleh masyarkat Ngempon masih dalam keadaan runtuh/rusak dan terpendam tanah. Candi ngempon ditemukan oleh Bapak Kasri beserta Kakeknya yakni Bapak Muali sebagai penggarap lahan tempat ditemukan Situs Candi Ngempon. Situs ini ditemukan pada tahun 1951, dimana pada waktu itu Kelurahan Ngempon sedang melangsungkan proses pembangunan Masjid, dalam proses pembangunan masjid tersebut masyarakat memanfaatkan batu-batu yang diperoleh di area lahan tempat ditemukannya Situs Candi Ngempon, kemudian ditengah proses pembangunan masjid tersebut material batu yang dibutuhkan masih kurang sehingga Bapak Kasri dan Kakeknya diperintah untuk mencari kembali batu tambahan, kemudian ketika proses pencarian batu Bapak Kasri menemukan sebuah arca salah satu dewa Hindu yakni Dewa Siwa, sehingga Bapak Kasri diperintahkan untuk mencari dan mengumpulkan kembali batu-batu lainnya oleh kepala desa Ngempon pada saat itu untuk memenuhi susunan bangunan sebuah candi.

Menurut Bapak Paryono selaku petugas yang dimanahi untuk merawat Situs Candi Ngempon yang merupakan putra Bapak Kasri penemu pertama Situs Candi Ngempon arca yang ditemukan telah dilaporkan ke Dinas Purbakala pada tahun 1952, kemudian pada tahun 1953 Dinas Purbakala mendatangi lokasi ditemukanya situs Candi Ngempon dan tanah milik Bapak Kasri dibeli oleh Dinas Purbakala untuk dijadikan sebagai cagar budaya. Situs Candi Ngempon terdiri dari sembulan candi, yakni enam candi bear dan tiga candi kecil, namun hanya empat candi yang dapat dipugar sehingga saat ini yang terlihat hanya ada empat candi yang berdiri. Situs Candi Ngempon diperbaiki sekitar tahun 1956 dan pada tahun 1976 disusun hingga berdiri dua candi dan dilanjutkan lagi pada tanggal 25 juni tahun 2009 disusun lagi dua candi disebelah timur hingga sekarang masih berjumlah 4 candi yang berdiri. Menurut keterangan Bapak Kasri Candi Ngempon terdiri dari sembilan candi, enam bangunan tersebut terdiri dari satu Candi Induk dan lima Candi Perwara yang letaknya saling berhadapan. Candi Induk dan dua Candi Perwara terletak di sebelah selatan dan utara Candi Induk memiliki arah hadap ke timur, sedangkan ketiga Candi Perwara menghadap ke arah barat.

Berdasarkan gaya arsitekturnya Candi Ngempon merupakan candi Hindu Syiwa yang diperlukan untuk pemujaan. Diperkirakan sezaman dengan Candi Gedongsongo dan memiliki keterkaitan. Candi Ngempon tidak memiliki kegunaan yang sangat berarti karena Candi Ngempon bukan merupakan candi yang digunakan untuk ritual, adanya candi ngempon di daerah Ngempon diperkirakan sebagai persembahan orang-orang kaya pada jaman dahulu. Candi Ngempon merupakan tempat sebagai penggemblengan kasta Brahmana yang dididik sebagi mpu atau empu, di area situs Candi Ngempon terdapat keterangan bahwa Candi Ngempon terdiri dari enam bangunan meliputi satu Candi Induk dan lima Candi Perwara , akan tetapi menurut Ibu Ufi Saraswati bangunan Candi Ngempon bukan merupakan Candi Perwara dikarenakan besar ukuran candicandi tersebut sepintas tampak sama hanya satu candi yang berukuran sedikit lebih besar (Ufi Saraswati dalam Farhatin, 2016).

Situs ini bisa menjadi salah satu sumber belajar IPS yang efektif serta menyenangkan dan meningkatkan daya tarik peserta didik dalam mempelajari situs sejarah, terutama situs sejarah yang terdapat di lingkungan sekitar. Situs Candi Ngempon ini pula bisa di manfaatkan sebagai sumber belajar IPS yang efektif bagi peserta didik di SMP Negeri 1 Bergas, hal ini karena Situs Candi Ngempon merupakan salah satu contoh peinggalan sejarah pada masa Hindu-Budhha yang terdapat di lingkungan SMP Negeri 1 Bergas, dengan dukungan lingkungan Candi Ngempon yang memiliki potensi-potensi lain yang dapat menjadi daya dukung dalam upaya pencapaian indikator lain dalam keterpaduan IPS yang tercantum dalam kurikulum 2013, dimana di lingkungan sekitar Candi Ngempon terdapat batu-batu besar, sumber air panas dan kondisi keanekaragaman masyarakat yang ada disekitar Candi Ngempon, dengan hal ini maka Candi Ngempon merupakan salah satu obyek wisata yang komplit untuk dimanfaatkan sebagai sumber belajar IPS sesuai dengan konsep keterpaduan Pendidikan IPS dalam kurikulum 2013. Pemanfaatan Situs Candi Ngempon sebagai sumber belajar IPS di SMP Negeri 1 Bergas diharapkan peserta didik dapat memahami pembelajaran IPS dengan baik dan 
dapat mengenal situs sejarah yang dimiliki daerahnya yakni Kecamatan Bergas.

Berdasarkan uraian tersebut, peneliti tertarik untuk melakukan penelitian dengan judul "Efektivitas Pemanfaatan Poster Candi Ngempon Sebagai Sumber Belajar IPS pada Materi Peninggalan-Peninggalan Masa HinduBuddha Kelas VII di SMP Negeri 1 Bergas".

\section{METODE}

\section{Desain Penelitian}

Penelitian ini merupakan penelitian jenis eksperimen, dimana dalam penelitian ini peneliti melakukan kegiatan penelitian efektivitas pemanfaatan Situs Candi Ngempon sebagai sumber belajar IPS yang dalam hal ini pemanfaatan sumber belajar dalam bentuk poster. Alur penelitian yang dilaksanakan dalam kegiatan penelitian ini yakni mengacu pada penelitian pre test and pos test group, dimana pada kelas yang dijadikan sampel penelitian melaksanakan kegiatan pret tes sebelum diberikannya treatment dan setelah kegiatan treatment selesai kelas penelitian selanjutnya melaksanakan kegiatan post test, sehingga dalam hal ini terdapat dua kali observasi untuk kelas penelitian yakni sebelum diberikan treatmen dan setelah diberikannya treatment.

\section{Populasi dan sampel penelitian}

Populasi dalam peneitian ini adalah seluruh siswa kelas VII SMP Negeri 1 Bergas.

Sampel yang digunakan adalah kelas VII F sebagai kelas penelitian dan kelas VII B sebagai kelas uji coba. Teknik pengambilan sample menggunakan teknik random sampling (penyampelan secara acak). Pengambilan sampel dilakukan secara acak dengan cara mengundi semua kelas VII yang ada di SMP Negeri 1 Bergas. satu kelas akan dipilih untuk kelas penelitian dan satu kelas untuk uji coba soal yang akan digunakan sebagai soal pre test dan post tes yang akan diujikan pada kelas penelitian.

Alat, Teknik pengumpulan data, dan teknik analisis data.

Alat dan teknik pengumpulan data dalam penelitian ini yaitu dokumentasi, kuesioner/ angket, dan tes.

Teknik analisis data yang digunakan adalah teknik analisis data statistik deskriptif. Pada penelitian ini pengujian hipotesis dilakukan dengan membandingkan nilai sebelum diberikan treatment pembelajaran dengan menggunakan poster candi Ngempon melalui pre test dan setelah diberikan treatment pembelajaran dengan menggunakan poster candi Ngempon melalui post test.

\section{HASIL DAN PEMBAHASAN}

Aktivitas belajar peserta didik

Data aktivitas belajar peserta didik diperoleh melalui pengamatan peneliti saat kegiatan belajar mengajar berlangsung, terutama pada saat pembelajaran IPS dengan pembelajaran memanfaatkan Situs Candi Ngempon sebagai sumber belajar. Pemanfaatan Situs Candi Ngempon sebagai sumber belajar IPS diterapkan dalam materi peninggalan masa Hindu-Buddha di kelas VII F. Data aktivitas belajar peserta didik diambil berdasarkan indikator-indikator yang tertuang dalam lembar observer penelitian yang mana lembar observer tersebut mencakup beberapa aspek yang harus diamati oleh peneliti. Hasil pengamatan aktivitas belajar peserta didik kelas VII F adalah sebagai berikut:

Tabel 1 kriteria aktivitas belajar peserta didik

\begin{tabular}{|c|c|c|c|c|}
\hline \multirow{2}{*}{$\begin{array}{l}\mathbf{N} \\
\mathbf{0}\end{array}$} & \multirow{2}{*}{$\begin{array}{c}\text { Interval } \\
\text { Skor }\end{array}$} & \multirow[t]{2}{*}{ Kriteria } & \multicolumn{2}{|c|}{ Jumlah } \\
\hline & & & $\mathbf{F}$ & $\%$ \\
\hline 1. & $16-27$ & Rendah & 0 & 0 \\
\hline 2. & $28-39$ & Cukup & 3 & 9,67 \\
\hline 3. & $40-51$ & Tinggi & 19 & 61,29 \\
\hline 4. & $52-64$ & $\begin{array}{l}\text { Sangat } \\
\text { tinggi }\end{array}$ & 9 & 29,03 \\
\hline \multicolumn{3}{|c|}{ Jumlah } & 31 & 100 \\
\hline
\end{tabular}

Sumber: data peneliti 2020

Berdasarkan tabel 1 aktivitas peserta didik kelas VII F dapat diketahui sebanyak 9,67 $\%$ termasuk dalam kriteria cukup dengan jumlah sebanyak 3 peserta didik, 61,29\% termasuk dalam kriteria tinggi dengan jumlah sebanyak 19 peserta didik, dan sebesar 29,03\% aktivitas peserta didik termasuk dalam kategori sangat tinggi dengan jumlah sebanyak 9 peserta didik.

\section{Hasil belajar peserta didik}

Hasil belajar peserta didik diukur berdasarkan aspek kognitif peserta didik yang diperoleh melalui kegiatan pre test dan post test yang dilakukan di kelas VII F. Kegiatan pre test dilakukan sebelum diberikannya treatment dalam hal ini yakni pemanfaatan Situs Candi Ngempon sebagai sumber belajar IPS dalam kegiatan pembelajaran. Sedangkan post tes merupakan proses pengambilan data setelah dilaksanakannya treatment pemanfaatan Situs Candi Ngempon sebagai sumber belajar IPS dalam kegiatan pembelajaran. Data yang didapatkan dari kegiatan pre test adalah sebagai berikut: 
Tabel 2 hasil pre test peserta didik

\begin{tabular}{|c|c|c|c|}
\hline \multirow[t]{2}{*}{ No } & \multirow[t]{2}{*}{ Interval } & \multicolumn{2}{|c|}{ Jumlah } \\
\hline & & $\mathbf{F}$ & $\%$ \\
\hline 1. & $20-26$ & 1 & 3,57 \\
\hline 2. & $27-33$ & 5 & 17,85 \\
\hline 3. & $34-40$ & 6 & 21,24 \\
\hline 4. & $41-47$ & 8 & 28,57 \\
\hline 5. & $48-54$ & 5 & 17,85 \\
\hline 6. & $55-61$ & 1 & 3,57 \\
\hline 7. & $62-68$ & 2 & 7,14 \\
\hline \multicolumn{2}{|c|}{ Jumlah } & 28 & 100 \\
\hline \multicolumn{2}{|c|}{ Nilai tertinggi } & \multicolumn{2}{|l|}{64} \\
\hline \multicolumn{2}{|c|}{ Nilai terendah } & \multicolumn{2}{|l|}{20} \\
\hline \multicolumn{2}{|c|}{ Jumlah tuntas } & \multicolumn{2}{|l|}{0} \\
\hline \multicolumn{2}{|c|}{ Rata-rata nilai } & \multicolumn{2}{|l|}{41,85} \\
\hline
\end{tabular}

Sumber: data peneliti 2020

Tabel 2 merupakan tabel hasil pre test kelas VII F. Berdasarkan tabel tersebut dapat diketahui pada kelas pertama hasil pre test sebanyak $3,57 \%$ peserta didik mendapatkan nilai dengan rentan 20-26, dengan frekuensi 1 yang artinya dalam hal ini terdapat satu peserta didik yang mendapatkan nilai dengan rentan 20-26. Pada kelas kedua hasil pre test sebanyak $17,85 \%$ peserta didik mendapatkan nilai dengan rentan 27-33, dengan frekuensi 5 yang artinya dalam hal ini terdapat lima peserta didik yang mendapatkan nilai dengan rentan 27-33. Pada kelas ketiga hasil pre test sebanyak 21,24\% peserta didik mendapatkan nilai dengan rentan 34-40, dengan frekuensi 6 yang artinya dalam hal ini mendapatkan nilai dengan rentan 34-40. Pada kelas keempat hasil pre test sebanyak $28,57 \%$ peserta didik mendapatkan nilai dengan rentan 41-47, dengan frekuensi 8 yang artinya dalam hal ini terdapat delapan peserta didik yang mendapatkan nilai dengan rentan 41-47. Pada kelas kelima hasil pre test sebanyak 17,85\% peserta didik mendapatkan nilai dengan rentan 48-54, dengan frekuensi 5 yang artinya dalam hal ini terdapat lima peserta didik yang mendapatkan nilai dengan rentan 48-54. Pada kelas keenam hasil pre test sebanyak 3,57\% peserta didik mendapatkan nilai dengan rentan 55-61, dengan frekuensi 1 yang artinya dalam hal ini terdapat satu peserta didik yang mendapatkan nilai dengan rentan 55-61. Selanjutnya, pada kelas ketuju hasil pre test sebanyak $7,14 \%$ peserta didik mendapatkan nilai dengan rentan 62-68, dengan frekuensi 2 yang artinya dalam hal ini terdapat dua peserta didik yang mendapatkan nilai dengan rentan 62-68.

Berdasarkan nilai pre test kelas VII F pada materi peninggalan masa Hindu-Buddha dapat diketahui nilai tertinggi yang diperoleh peserta didik dalam kelas tersebut adalah 64 dan nilai terendah adalah 20. Kriteria Ketuntasan Minimal (KKM) yang berlaku di SMP Negeri 1 Bergas adalah 75, sehingga berdasarkan hasil pre test tersebut peserta didik dalam hal ini tidak ada yang memenuhi nilai KKM atau tidak ada yang peserta didik yang berhasil tuntas. Nilai ratarata hasil pre tes tersebut adalah 41,85.

Langkah selanjutnya dalam penelitian ini setelah data pre tes diperoleh yakni dengan memberikan treatment dalam menerapakan pembelajaran menggunakan Situs Candi Ngempon sebagai sumber belajar IPS untuk kelas VII F, dan setelah treatment selesai diberikan maka langkah selanjutnya yaitu pelaksanaan post test. Data hasil post test kelas VII F SMP Negeri 1 Bergas adalah sebagai berikut:

Tabel 3 hasil post test peserta didik

\begin{tabular}{|c|c|c|c|}
\hline \multirow[t]{2}{*}{ No } & \multirow[t]{2}{*}{ Interval } & \multicolumn{2}{|c|}{ Jumlah } \\
\hline & & $\mathbf{F}$ & $\%$ \\
\hline 1. & $56-61$ & 4 & 13,33 \\
\hline 2. & $62-67$ & 0 & 0 \\
\hline 3. & $68-73$ & 11 & 36,66 \\
\hline 4. & 74-79 & 6 & 20,00 \\
\hline 5. & $80-85$ & 7 & 23,33 \\
\hline 6. & $86-91$ & 2 & 6,66 \\
\hline \multicolumn{2}{|c|}{ Jumlah } & 30 & 100 \\
\hline \multicolumn{2}{|c|}{ Nilai tertinggi } & \multicolumn{2}{|l|}{92} \\
\hline \multicolumn{2}{|c|}{ Nilai terendah } & \multicolumn{2}{|l|}{56} \\
\hline \multicolumn{2}{|c|}{ Jumlah tuntas } & \multicolumn{2}{|l|}{15} \\
\hline \multicolumn{2}{|c|}{ Rata-rata nilai } & \multicolumn{2}{|c|}{73,73} \\
\hline
\end{tabular}

Sumber: data peneliti 2020

Tabel 3 merupakan tabel hasil post test peserta didik kelas VII F SMP Negeri 1 Bergas. Berdasarkan tabel tersebut dapat diketahui pada kelas pertama hasil post test sebanyak 13,33\% peserta didik mendapatkan nilai dengan rentan 56-61, dengan frekuensi 4 yang artinya dalam hal ini terdapat empat peserta didik yang mendapatkan nilai dengan rentan 56-61. Pada kelas kedua hasil post test sebanyak $0 \%$ peserta didik mendapatkan nilai dengan rentan 62-67, dengan frekuensi 0 yang artinya dalam hal ini tidak terdapat peserta didik yang mendapatkan nilai dengan rentan 62-67. Pada kelas ketiga hasil post test sebanyak $36,66 \%$ peserta didik mendapatkan nilai dengan rentan 68-73, dengan frekuensi 11 yang artinya dalam hal ini terdapat sebelas peserta didik yang mendapatkan nilai dengan rentan 68-73. Pada kelas keempat hasil post test sebanyak $20,00 \%$ peserta didik mendapatkan nilai dengan rentan 74-79, dengan frekuensi 6 yang artinya dalam hal ini terdapat 
enam peserta didik yang mendapatkan nilai dengan rentan 74-79. Pada kelas kelima hasil post test sebanyak 23,33\% peserta didik mendapatkan nilai dengan rentan 80-85, dengan frekuensi 7 yang artinya dalam hal ini terdapat tujuh peserta didik yang mendapatkan nilai dengan rentan 80-85. Selanjutnya pada kelas keenam hasil post test sebanyak $6,66 \%$ peserta didik mendapatkan nilai dengan rentan 86-91, dengan frekuensi 2 yang artinya dalam hal ini terdapat dua peserta didik yang mendapatkan nilai dengan rentan 86-91.

Berdasarkan data hasil post test tersebut maka dapat diketahui jumlah peserta didik yang mampu mencapai nilai Kriteria Ketuntasan Minimal (KKM) adalah sebanyak 15 peserta didik, dengan nilai tertinggi yang diperoleh yakni 92 dan nilai terendah yang diperoleh peserta didik yakni 56, dengan rata-rata nilai 73.73 , sehingga dengan ini dapat diketahui terdapat peningkatan setelah adanya treatment dalam pembelajaran yakni dengan memanfaatkan Situs Candi Ngempon sebagai sumber belajar IPS.

Uji Normalitas Pre test dan Post Test

Uji nomalitas dalam penelitian ini dilakukan dengan menggunakan uji shapiro-Wilk, uji shapiro-wilk digunakan dengan ketentuan jumlah responden yang digunakan kurang dari 30 orang. Data dikatakan sebagai data berdistribusi normal jika data diatas 0,05. Hasil uji normalitas pre tes dan post tes dalam penelitian ini adalah sebagai berikut:

Tabel 4 hasil uji normalitas pre tes dan post tes

Tests of Normality

\begin{tabular}{|c|r|r|r|r|r|r|}
\hline & \multicolumn{3}{|c|}{$\begin{array}{c}\text { Kolmogorov- } \\
\text { Smirnov }\end{array}$} & \multicolumn{3}{c|}{ Shapiro-Wilk } \\
\cline { 2 - 7 } & $\begin{array}{c}\text { Stati } \\
\text { stic }\end{array}$ & df & Sig. & $\begin{array}{c}\text { Stati } \\
\text { stic }\end{array}$ & df & Sig. \\
\hline $\begin{array}{c}\text { Pre } \\
\text { test } \\
\begin{array}{c}\text { Post } \\
\text { test }\end{array}\end{array}$ &, 151 & 27 &, 119 &, 950 & 27 &, 211 \\
\hline \multicolumn{4}{c|}{ Sumber: Data peneliti 2020 } \\
\hline
\end{tabular}

Berdasarkan tabel 4 hasil uji normalitas shapirowilk maka dapat diketahui data pret tes dan post tes dalam penelitian ini adalah data yang berdistribusi normal, dimana dalam tabel tersebut diketahui bahwasanya sig pre test sebesar 0,211 dan sig post tes sebesar 0,101.

\section{Uji Perbedaan rata-rata}

Uji perbedaan rata-rata digunakan untuk mengetahui perbedaan nilai pre test dan nilai post test pada kelas penelitian sebagai kelas yang menggunakan Situs Candi Ngempon sebagai sumber belajar IPS dalam proses pembelajarannya. Uji perbedaan rata-rata dalam penelitian ini yakni melalui uji paired sample $t$ test, dalam uji paired sample $t$ test $\mathrm{Ha}$ dapat diterima dan Ho di tolak jika nilai Sig (2-tailed) lebih kecil dari 0,05, kemudian Ha ditolak dan Ho ditolak jika Sig (2-tailed) lebih besar dari 0,05. Rumusan Hipotesisnya adalah sebagai berikut: Ha: terdapat perbedaan rata-rata dari hasil belajar pre test dan post tes.

Ho: tidak terdapat perbedaan rata-rata dari hasil belajar pre test dan post tes.

Berdasarkan rumusan hipotesisi tersebut maka peneliti dapat menganalisis kembali berdasarkan hasil uji perbedaan ratarata sebagai berikut :

Tabel 5 hasil uji perbedaan rata-rata

Paired Samples Test

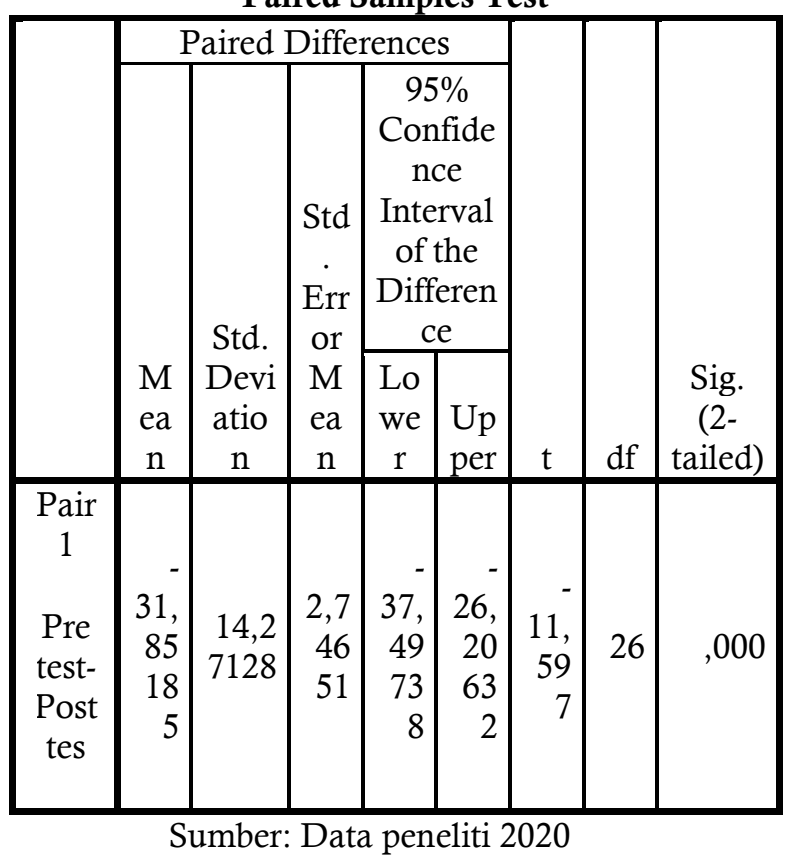

Tabel 5 merupakan tabel hasil uji perbedaan rata-rata pre test pos test kelas VII F, berdasarkan tabel tersebut dapat diketahui bahwa nilai sig (2tailed) sebesar 0.000 atau hasil uji perbedaan rata-rata pre tes post tes lebih kecil dari 0.05 , sehingga dalam penlitian ini $\mathrm{Ha}$ dapat diterima dan Ho di tolak yang artinya terdapat perbedaan rata-rata hasil belajar pre tes dan post tes atau bisa dikatakan terdapat pengaruh penggunaan Situs Candi Ngempon sebagai sumber belajar IPS kelas VII di SMP Negeri 1 Bergas.

\section{Respon peserta didik terhadap pembelajaran}

Data respon peserta didik terhadap pembelajaran dengan memanfaatkan Situs Candi Ngempon sebagai sumber belajar IPS diperoleh 
dari angket. Peserta didik setelah mendapatkan pembelajaran menggunakan Situs Candi Ngempon sebagai sumber belajar selanjutnya pada pertemuan terakhir peserta didik mengisi angket secara langsung berdasarkan pendapat sesuai dengan apa yang dirasakan oleh peserta didik selama proses pembelajaran.

Tabel 6 Kriteria respon peserta didik

\begin{tabular}{|c|c|c|c|c|}
\hline \multirow[t]{2}{*}{ No } & \multirow{2}{*}{$\begin{array}{c}\text { Interval } \\
\text { Skor }\end{array}$} & \multirow[t]{2}{*}{ Kriteria } & \multicolumn{2}{|c|}{ Jumlah } \\
\hline & & & $\mathbf{F}$ & $\%$ \\
\hline 1. & $10-17$ & Kurang (D) & 0 & \\
\hline 2. & $18-25$ & Cukup (C) & 3 & 9,67 \\
\hline 3. & $26-33$ & Baik (B) & 23 & 74,19 \\
\hline 4. & $34-41$ & $\begin{array}{l}\text { Sangat baik } \\
\text { (A) }\end{array}$ & 5 & 16,12 \\
\hline \multicolumn{3}{|c|}{ Jumlah } & 31 & 100 \\
\hline
\end{tabular}

Sumber: data peneliti 2020

Berdasarakan tabel 6 Respon peserta didik kelas VII F dapat diketahui sebanyak 9,67\% peserta didik memberikan respon cukup yakni dengan jumlah 3 peserta didik, 74,19\% peserta didik memberikan respon baik yakni dengan jumlah 23 peserta didik dan sebesar 16,12\% peserta didik memberikan respon sangat baik yakni dengan jumlah 5 peserta didik setelah proses pembelajaran menggunakan Situs Candi Ngempon sebagai sumber belajar IPS diterapkan. Hal ini menunjukan bahwasanya sebagian besar peserta didik merespon dengan baik pembelajaran dengan memanfaatkan Situs Candi Ngempon sebagai sumber belajar IPS

\section{Pembahasan}

Penelitian ini merupakan penelitian yang bertujuan untuk menganalisis efektivitas pemanfaatan Situs Candi Ngempon sebagai sumber belajar IPS di SMP Negeri 1 Bergas dengan fokus materi peninggalan masa HinduBuddha, mengetahui kelayakan Situs Candi Ngempon sebagai sumber belajar IPS serta bagaimana bentuk pemanfaatannya dalam pembelajaran IPS.

Efektivitas berasal dari kata efektif, yang berarti dapat membawa hasil, berhasil guna, terdapat efek, pengaruh, akibat, dan kesannya. Berdasarkan PP 19 Tahun 2005 SNP suasana pembelajaran yang efektif adalah pembelajaran dengan suasana belajar di kelas yang interaktif, inspiratif, menyenangkan, menantang, inovatif dan menemukan sendiri, jadi pembelajaran yang efektif merupakan pembelajaran yang memiliki karakteristik peserta didik melihat, mendengarkan, mendemonstrasikan, bekerja sama, menemukan, dan membangun konsep sendiri (Amri, 2013). Menurut Sani (2014) efektivitas pembelajaran tidak terlepas dari aktivitas yang berkualitas dalam perencanaan, pelaksanaan, dan evaluasi yang dilakukan oleh guru Sinambela (dalam Fani Fadillasari, 2017) mengungkapkan bahwasanya pelaksanaan pembelajaran bisa dikatakan efektif jika tiga kriteria dari empat kriteria berikut dapat terpenuhi, yaitu:

1) kemampuan guru dalam mengelola pembelajaran efektif.

2) aktivitas siswa efektif

3) ketuntasan hasil belajar secara klasikal tuntas atau efektif

4) respon/ tanggapan siswa terhadap pembelajaran positif.

Berdasarkan kriteria pembelajaran yang efektif diatas maka indikator untuk mengetahui efektivitas pemanfaatan Situs Candi Ngempon sebagai sumber belajar IPS di SMP Negeri 1 Bergas dengan pokok pembahasan peninggalan masa Hindu-Buddha dapat diketahui melalui aktivitas peserta didik, hasil belajar peserta didik, dan respon positif peserta didik. Analisis untuk mengetahui efektivitas pemanfaatan Situs Candi Ngempon sebagai sumber belajar IPS di SMP Negeri 1 Bergas adalah sebagai berikut:

\section{Aktivitas belajar peserta didik}

Hasil pengamatan aktivitas peserta didik dalam penelitian ini dilakuakan saat proses belajar mengajar berlangsung yang kemudian difokuskan pada saat kegiatan diskusi dalam pembelajaran IPS dengan pokok materi peninggalan masa Hindu-Buddha yang mana dalam proses pembelajarannya memanfataakan Situs Candi Ngempon sebagai sumber belajar IPS dalam bentuk poster. Kelas yang menjadi objek dalam penlitian ini adalah kelas VII F.

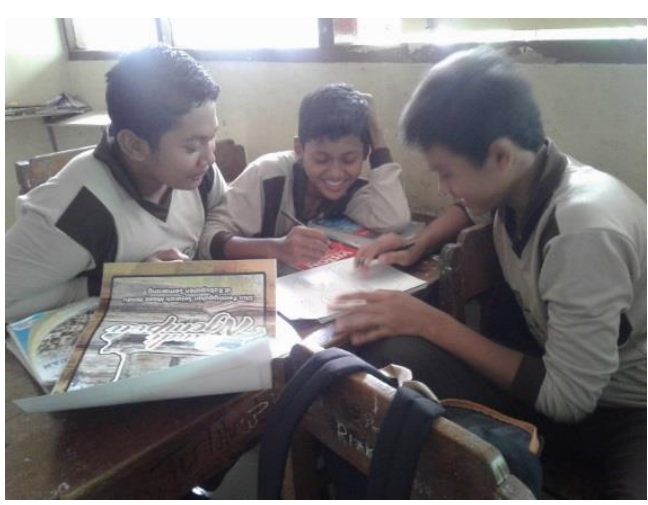

Gambar 1 diskusi kelompok peserta didik setelah peserta didik mendapatkan penjelasan materi peninggalan-peninggalan masa Hindu-Buddha dengan menggunakan poster sebagai sumber belajar IPS selanjutnya, peserta didik dibagi menjadi delapan kelompok yang kemudian masing-masing kelompok diminta untuk mendiskusikan pertanyaanpertanyaan yang telah diajukan dan 
mengkorelasikannya dengan poster Situs Candi Ngempon, output dari kegiatan diskusi ini yakni berupa lembar kerja siswa yang selanjutnya di presentasikan didepan kelas dengan hasil korelasi materi, lembar kerja dan poster Situs Candi Ngempon.

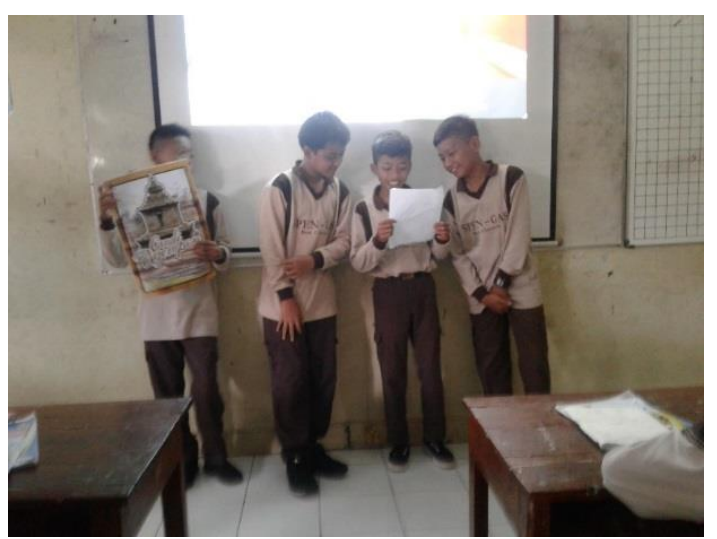

Gambar 2 peserta didik mempresentasikan hasil diskusi kelompok

Gambar 2 adalah gambar kegiatan presentasi peserta didik perwakilan dari delapan kelompok yang terbentuk, dalam kegiatan presentasi ini aktivitas peserta didik yang muncul adalah kegiatan bertanya dan menjawab antara kelompok satu dengan kelompok lainnya sehingga dari aktivitas peserta didik ini mampu memberikan peluang untuk bertukar informasi dan pengetahuan terutama yang berkaitan dengan materi peninggalan-peninggalan masa Hindu-Budhha.

Tabel 7 Kriteria aktivitas belajar peserta didik

\begin{tabular}{|l|l|l|l|l|}
\hline \multirow{2}{*}{ No } & Interval & \multirow{2}{*}{ Kriteria } & \multicolumn{2}{|c|}{ Jumlah } \\
\cline { 4 - 5 } & Skor & & F & \multicolumn{1}{|c}{$\%$} \\
\hline 1. & $16-27$ & Rendah & 0 & 0 \\
\hline 2. & $28-39$ & Cukup & 3 & 9,67 \\
\hline 3. & $40-51$ & Tinggi & 19 & 61,29 \\
\hline 4. & $52-64$ & $\begin{array}{l}\text { Sangat } \\
\text { tinggi }\end{array}$ & 9 & 29,03 \\
\hline \multicolumn{3}{|c|}{ Jumlah } & $\mathbf{3 1}$ & $\mathbf{1 0 0}$ \\
\hline
\end{tabular}

Sumber: Data peneliti 2020

Berdasarkan penilaian aktivitas peserta didik di SMP Negeri 1 Bergas yakni pada kelas VII $F$ dapat disimpulkan pelaksanaan pembelajaran dengan memanfaatkan Situs Candi Ngempon sebagai sumber belajar IPS yang dalam hal ini berbentuk poster tergolong dalam kategori baik, yakni dari total 31 peserta didik sebanyak 19 peserta didik mampu mencapai kriteria tinggi dan 9 peserta didik tergolong dalam kriteria sangat tinggi, serta tidak terdapat peserta yang termasuk dalam kriteria rendah.

\section{Hasil belajar peserta didik}

Data hasil belajar peserta didik diperoleh erdasarkan penilaian yang ditinjau berdasarkan ranah kognitif, tahapan dalam pengambilan data hasil belajar peserta didik dalam ranah kognitif yaitu melalui dua tahap, tahap pertama yaitu melalui kegiatan pre test, dimana kegiatan ini dilaksanakan sebelum diberikannya treatment, tahap kedua yaitu melalui kegitan post test, selanjutnya data yang diperoleh dianalisis untuk mengetahui tingkat keefektivan pemanfaatan Situs Candi Ngempon sebagai sumber belajar IPS di SMP Negeri 1 Bergas. Berdasarkan kegiatan pre test yang dilakukan di kelas VII F dapat diperoleh hasil yakni dengan rata-rata nilai sebesar 41,85 yang artinya tingkat pencapaian peserta didik dalam Kriteria Ketuntasan Minimal (KKM) masih kurang, karena KKM yang ditetapkan di SMP Negeri 1 Bergas untuk mata pelajaran IPS yaitu peserta didik harus mencapai nilai minimal 75 , dari hasil pre test juga diketahui untuk peserta didik kelas VII F nilai tertinggi yang dicapai yakni 64 yang artinya belum ada peserta didik yang dapat mencapai nilai KKM.

Selanjutnya, setelah nilai pre test diketahui kemudian kelas VII F diberikan treatment yakni pembelajaran IPS dengan memanfaatkan Situs Candi Ngempon sebagai sumber belajarnya, yang mana dalam hal ini pemanfaatan tersebut dalam bentuk poster. Setelah kegiatan pemberian treatment pada peserta didik selesai maka kegiatan selanjutnya adalah dilakukannya post test.

Hasil kegiatan belajar peserta didik yakni kegiatan post test dalam penelitian ini yaitu nilai tetinggi yang dicapai peserta didik adalah 92 dengan rata-rata nilai sebesar 73,73 , peserta didik yang mampu mencapai nilai dengan rentan 74-76 sebanyak enam peserta didik, peserta didik yang mampu mencapai nilai dengan rentan 80-85 sebanyak tujuh peserta didik, dan peserta didik yang mampu mencapai nilai dengan rentan 86-91 sebanyak dua peserta didik, yang artinya dari total peserta didik mengikuti kegiatan post test yaitu 30 peserta didik sebanyak 15 peserta didik mampu mencapai nilai KKM, yang artinya terdapat peningkatan dari sebelum diberikannya treatment dimana tidak terdapat peserta didik yang mampu mencapai nilai KKM dan setelah diberikannya treatment sebanyak 15 peserta didik mampu mencapai nilai KKM.

Kesimpulannya adalah terdapat peningkatan rata-rata hasil belajar peserta didik sehingga tujuan pembelajaran dapat dikatakan tercapai sesuai rencana dan harapan. Hal ini dapat dilihat berdasarkan peningkatan hasil belajar peserta didik dalam ranah kognitif yakni peningkatan rata-rata nilai pre test dan post test yaitu 41,85 untuk rata-rata nilai pre test dan 73,73 untuk rata-rata nilai post test, sehingga 
pembelajaran IPS dengan memanfaatkan Situs Candi Ngempon sebagai sumber belajar yang dalam hal ini berbentuk poster dapat dikatakan efektif.

\section{Respon peserta didik terhadap pembelajaran}

Data respon peserta didik terhadap pembelajaran dengan memanfaatkan Situs Candi Ngempon sebagai sumber belajar IPS yang dalam hal ini dalam bentuk poster diperoleh dari angket yang dibagikan setelah kegiatan pemberian treatment selesai. Peserta didik mengisi angket tersebut berdasarkan pendapat yang sesuai dengan apa yang dirasakan oleh peserta didik selama mengikuti pembelajaran dengan memanfaatkan Situs Candi Ngempon Sebagai sumber belajar IPS yang dalam hal ini dalam bentuk poster.

Berdasarkan analisis hasil angket respon peserta didik terhadap pembelajaran IPS di SMP Negeri 1 Bergas yakni pada kelas VII F dapat disimpulkan pelaksanaan pembelajaran dengan memanfaatkan Situs Candi Ngempon sebagai sumber belajar IPS yang dalam hal ini berbentuk poster tergolong dalam kategori baik, yakni dari total 31 peserta didik sebanyak lima peserta didik termasuk dalam kategori sangat baik yakni mendapatkan skor dalam rentan 34-41, sebanyak 23 peserta didik termasuk dalam kategori baik yakni mendapatkan skor dalam rentan 26-33, dan sebanyak tiga peserta didik termasuk dalam kategori cukup yakni mendapatkan skor dalam rentan 18-25, dimana kelas interval skor terendah adalah 10 dan kelas interval skor tertinggi adalah 41, sehingga dari data tersebut dapat disimpulkan lebih dari $75 \%$ peserta didik mampu mencapai kriteria baik dan sangat baik, 9,67\% peserta didik termasuk dalam kategori cukup dan $0 \%$ peserta didik yang termasuk dalam kriteria kurang.

\section{SIMPULAN}

Berdasarkan hasil penelitian dan pembahasan pemanfaatan Situs Candi Ngempon sebagai sumber belajar IPS di SMP Negeri 1 Bergas yang dalam hal ini dalam bentuk poster Situs Candi Ngempon di kelas VII F pada materi peninggalan-peninggalan masa Hindu-Budhha efektif untuk diterapkan. Tingkat kefektifan pemanfaatan situs Candi Ngempon sebagai sumber belajar IPS yang dalam hal ini dalam bentuk poster dapat dilihat melalui hasil penelitian suatu pembelajaran dapat dikatakan efektif yakni dengan tiga kriteria terpenuhi yaitu aktivitas belajar peserta didik dengan rata-rata nilai tinggi, hasil belajar kognitif, afektif, dan psikomotorik dengan rata-rata nilai tinggi, serta respon positif peserta didik terhadap pembelajaran dengan rata-rata nilai tinggi.
Sehingga dapat disimpulkan pemanfaatan Situs Candi Ngempon sebagai sumber belajar IPS dalam bentuk poster efektif untuk diterapkan dalam pembelajaran.

Pemanfaatan Situs Candi Ngempon sebagai sumber belajar IPS untuk kelas VII dengan fokus materi pembahasan peninggalanpeninggalan masa Hindu - Buddha efektif diterapakan dalam pembelajaran, sehingga pemanfaatan situs-situs sejarah lain di sekitar dapat pula dimanfaatkan kembali sebagai sumber belajar IPS.

Pemanfaatan Situs Candi Ngempon sebagai sumber belajar IPS perlu dikembangkan kembali agar dapat memberikan manfaat lebih dalam pembelajaran, terutama bagi peserta didik agar tujuan pembelajaran dapat tercapai lebih baik lagi.

\section{DAFTAR PUSTAKA}

Arsyad, Azhar. 2013. Media Pembelajaran. Jakarta: Rajawali Pers.

Azmi, Narizky. 2014. Pemanfaatan Sumber Belajar dalam Meningkatkan Kualitas Pembelajaran. Skripsi. Jakarta: UIN Syarif Hidayatullah.

Dimyati dan Mudjiono. 2009. Belajar dan Pembelajaran. Jakarta: PT. Rineka Cipta

Duhri, Desi Rahmawati. 2014. Pemanfaatan candi Sebagai Sumber Belajar IPS di SMP Kecamatan Kalasan Kabupaten Sleman. Skripsi. Yogjakarata: Universitas Negeri Yogyakarta.

Hamalik, Umar. 2007. Proses Belajar Mengajar. Jakarta: Bumi Aksara.

Jailani, M Syahran. 2016. Pengembangan Sumber Belajar Berbasis Karakter Peserta Didik (Ikhtiar optimalisasi Proses Pembelajaran Pendidikan Agama Islam (PAI). Jurnal Pendidikan Islam. Vol.10.2

Majid, Abdul. 2008. Perencanaan Pembelajaran: Mengembangkan Standar Kompetensi Guru. Bandung: PT Rosda Karya.

Farhatin, Duroh, dkk. 2016. Pemanfaatan Situs Candi Ngempon Sebagai Sumber Belajar Sejarah di MA Darul Ma'arif Pringapus. Indonesian Journal of History Education. Vol 4. 2

Mulianingsih, Ferani dkk. 2019. Pelatihan Pembuatan Media Pembelajaran Berbasis Kearifan Lokal Bagi Guru MGMP IPS SMP Kota Semarang Sebagai Wujud Konservasi Sosial Untuk Menghadapi Era Revolusi Industri 4.0. Harmony. Vol.4.1

Purnomo, Arif, dkk. 2016. Model Pembelajaran Ilmu Pengetahuan Sosial (IPS) Pada 
Materi Kontroversi (Controversy Issues) Widiastuti, Eko Heri. 2017. Pemanfaatan Di Sekolah Menengah Pertama (SMP) Lingkungan Sebagai Sumber Kota Semarang. Jurnal Penelitian Pembelajaran Mata Pelajaran IPS. Satya Pendidikan. Vol. $33.1 \quad$ Widya, Vol. 33.1

Santrianawati. 2018. Media dan Sumber Belajar. Wijianigsih, Untari. 2019. Museum daerah Yogyakarta: CV Budi Utama.

Salam, Rudi. 2017. Efektifitas Penanaman NilaiNilai Kebangsaan Melalui Metode Karyawisata Dalam Pembelajaran Lumajang Sebagai Sumber belajar Pembelajaran di Kabupaten Lumajang Tahun 2015-2017. Skripsi. Jember: Sejarah. Jurnal Profesi Keguruan. Vol.1.105Universitas Jember.

106 